\title{
EDUKASI KASUS LOW BACK PAIN MYOGENIK SISWA DENGAN MODALITAS INFRARED DAN WILLIAM FLEXION EXERCISE
}

\author{
Dian Cita Sari ${ }^{1)}$, Ismaningsih ${ }^{1)}$, Renni Hidayati Zein ${ }^{1),}$ Wirda Hayati ${ }^{2)}$ \\ ${ }^{1)}$ Program Studi Fisioterapi, Fakultas Kedokteran dan Ilmu Kesehatan Universitas \\ Abdurrab \\ 2) MAN 2 Pekanbaru \\ Email: dian.cita.sari@univrab.ac.id
}

\begin{abstract}
ABSTRAK
Banyaknya jam belajar yang ditawarkan sedikit banyak berpengaruh terhadap jumlah waktu rata-rata siswa melakukan aktivitas belajar di kelas dalam keadaan duduk. Kegiatan belajar mengajar bagi siswa yang duduk dikelas membutuhkan waktu yang lama antara 4-7 jam sehari. Posisi duduk yang statis untuk waktu yang lama akan menimbulkan rasa nyeri karena ketegangan pada punggung bagian belakang. Low Back pain Myogenik (LBP) atau nyeri punggung bawah yang berhubungan dengan stress/ strain otot punggung, tendon, dan ligament yang biasanya dirasakan setelah melakukan aktifitas berlebihan, seperti mengangkat beban berat dengan posisi yang salah, terlalu lama membungkuk, berdiri/duduk yang terlalu lama dengan posisi yang salah, nyeri punggung bawah yang timbul dapat mengakibatkan kehilangan dan menganggu produktivitas kerja. Modalitas Infrared merupakan terapi yang digunakan untuk meningkatkan aliran darah dan melemaskan jaringan sehingga dapat mengurangi nyeri dan memaksimalkan fungsional. Sedangkan William flexion exercise merupakan bentuk latihan fisik untuk mengurangi penekanan pada elemen posterior tulang belakang dan latihan ini dapat menjaga keseimbangan yang tepat antara kelompok otot-otot fleksor dan ekstensor postural. Pengabdian ini dilakukan di MAN 2 Pekanbaru, Metode Pengabdian ini adalah Penyuluhan yang dilengkapi Pemaparan Kasus, Demonstrasi, dan Diskusi.
\end{abstract}

Kata Kunci: Posisi Duduk, LBP, Siswa

\section{ABSTRACT}

Many study hours offered has more or less an effect on the amount of time the average student conducts classroom learning activities in a sitting state. Teaching and learning activities for students who sit in class take a long time between 4-7 hours a day. Static sitting position for a long time will cause pain due to tension in the back of the back. Low Back pain Myogenic (LBP) or low back pain associated with stress / strain of the back muscles, tendons, and ligaments which are usually felt after doing excessive activities, such as lifting heavy loads in the wrong position, bending too long, standing / sitting too long with the wrong position, lower back pain that arises can result in loss and disrupt work productivity. Infrared modality is a therapy used to improve blood flow and relax tissue so that it can reduce pain and maximize functional. Whereas William flexion exercise is a form of physical exercise to reduce the emphasis on the posterior element of the spine and this exercise can maintain the right balance between flexor muscle groups and postural extensors. This service was carried out in MAN 2 Pekanbaru, this Service Method was Conseling which was equipped with Case Explanations, Demonstrations, and Discussions.

Keywords: Sitting Position, LBP, Student 


\section{PENDAHULUAN}

Siswa atau peserta didik adalah mereka yang secara khusus diserahkan oleh kedua orangtuanya untuk mengikuti pembelajaran yang diselenggarakan di sekolah, dengan tujuan untuk menjadi manusia yang berilmu pengetahuan, berketrampilan, berpengalaman, berkepribadian, berakhlak mulia, dan mandiri.

Banyaknya jam belajar yang ditawarkan sedikit banyak berpengaruh terhadap jumlah waktu rata-rata siswa melakukan aktivitas belajar di kelas dalam keadaan duduk. Di sekolah, anak- anak menghabiskan sebagian besar waktu berada di kelas. Anak usia sekolah menghabiskan 30 persen waktunya selama di sekolah dengan posisi duduk (Syazwan et al, 2009). Masalah utama yang ditemukan pada aktivitas kerja dalam posisi duduk adalah kelelahan otot dan tulang bagian belakang yang disebabkan posisi duduk yang salah dalam waktu lama (Mulyono, 2010).

Kegiatan belajar mengajar bagi siswa yang duduk dikelas membutuhkan waktu yang lama antara 4-7 jam sehari. Posisi duduk yang statis untuk waktu yang lama akan menimbulkan rasa nyeri karena ketegangan pada punggung bagian belakang. Keluhan nyeri tersebut akan meningkat bila tinggi kursi terlalu pendek, duduk akan menbungkuk karena lutut akan lebih tinggi dibanding posisi pantat (Santoso, 2012).

Low Back pain Myogenik (LBP) atau nyeri punggung bawah yang berhubungan dengan stress/ strain otot punggung, tendon, dan ligament yang biasanya dirasakan setelah melakukan aktifitas berlebihan, seperti mengangkat beban berat dengan posisi yang salah, terlalu lama membungkuk, berdiri/duduk yang terlalu lama dengan posisi yang salah, nyeri punggung bawah yang timbul dapat mengakibatkan kehilangan dan menganggu produktivitas kerja.

Faktor resiko yang dapat mepengaruhi timbulnya low back pain antara lain umur, jenis kelamin, indeks massa tubuh(IMT), masa kerja, dan kebiasaan olahraga. Berdasarkan uraian di atas maka kami melaksanakan kegiatan pengabdian ini.

\section{TINJAUAN PUSTAKA}

Low Back Pain Myogenic juga didefinisikan sebagai nyeri akut pada daerah ruas lumbalis kelima dan sakralis L5-S1 yang disebabkan ketegangan otot fleksor atau ekstensor. Nyeri pada punggung bawah dirasakan oleh penderita dapat terjadi secara jelas atau samar serta menyebar atau terlokalisir.

Modalitas Infrared (IR) merupakan terapi yang digunakan untuk meningkatkan aliran darah dan melemaskan jaringan sehingga dapat mengurangi nyeri dan memaksimalkan fungsional (Ansari et al., 2014) .

William flexion exercise diperkenalkan oleh DR. Paul Williams pada tahun 1937. William flexion exercise merupakan terapi latihan atau latihan fisik yang digunakan fisioterapi untuk mempertahankan dan mengembalikan kesehatan fisik serta untuk menjaga sendi dan otot-otot tetap bergerak. William flexion exercise dapat mengurangi nyeri pinggang bawah (Kusuma \& Setiowati, 2015). William flexion exercise merupakan bentuk latihan fisik untuk mengurangi penekanan pada elemen posterior tulang belakang dan latihan ini dapat menjaga keseimbangan yang tepat antara kelompok otot-otot fleksor dan ekstensor postural. 


\section{METODE PELAKSANAAN}

Dalam rangka mencapai tujuan yang telah diuraikan diatas, maka pelaksanaan kegiatan pengabdian kepada masyarakat ini dilakukan dengan metode ceramah dan praktik yaitu memberikan penjelasan dan pembahasan kasus-kasus yang terkait dengan low back pain, metode IR, dan WFE.

Ada tiga metode yang di terapkan dalam program ini, yaitu metode presentasi, metode demonstrasi, dan metode praktek. Adapun langkah-langkah dalam pelaksaan program pelatihan ini adalah sebagai berikut:

1. Pra Kegiatan

a. Proses perijinan dimulai dengan membuat surat ijin dari universitas di tujukan lembaga pendidikan terkait tempat pengabdian dilakukan, sekaligus meminta bantuan untuk memeperoleh data siswa yang mengikuti program pelatihan. Target jumlah peserta adalah 30 orang.

b. Persiapan tempat dilakukan di aula MAN 2 Pekanbaru.

c. Persiapan alat, bahan dan perlengkapan dalam sosialisasi dan pelatihan dari mulai sepidol, penghapus, modul, banner, laptop, papan tulis, dan bolpoint. Penyusunan alat evaluasi berupa daftar kehadiran, dan simulasi.

2. Pelaksanaan kegiatan

Setelah memeperoleh ijin dari pihak terkait serta diperolehnya data dari peserta maka dilaksanakan sosialisasi program dengan peserta dan instansi terkait, lalu dibuat kesepakatan mengenai waktu pelaksanaan program.

\section{HASIL DAN PEMBAHASAN}

Program ini dilakukan dalam bentuk pelatihan dalam beberapa tahap.

Tahap I : Pemberikanan pengenalan kasus LBP

Tahap II : Mendemonstrasikan metode IR \& WFE

Tahap III : Siswa Memahami dan berdiskusi materi yang di ulas pada tahap II.

Tahap IV : Mengevaluasi pembelajaran yaitu dengan melihat hasil ulasan kesimpulan materi yang disampaikan oleh siswa peserta pelatihan
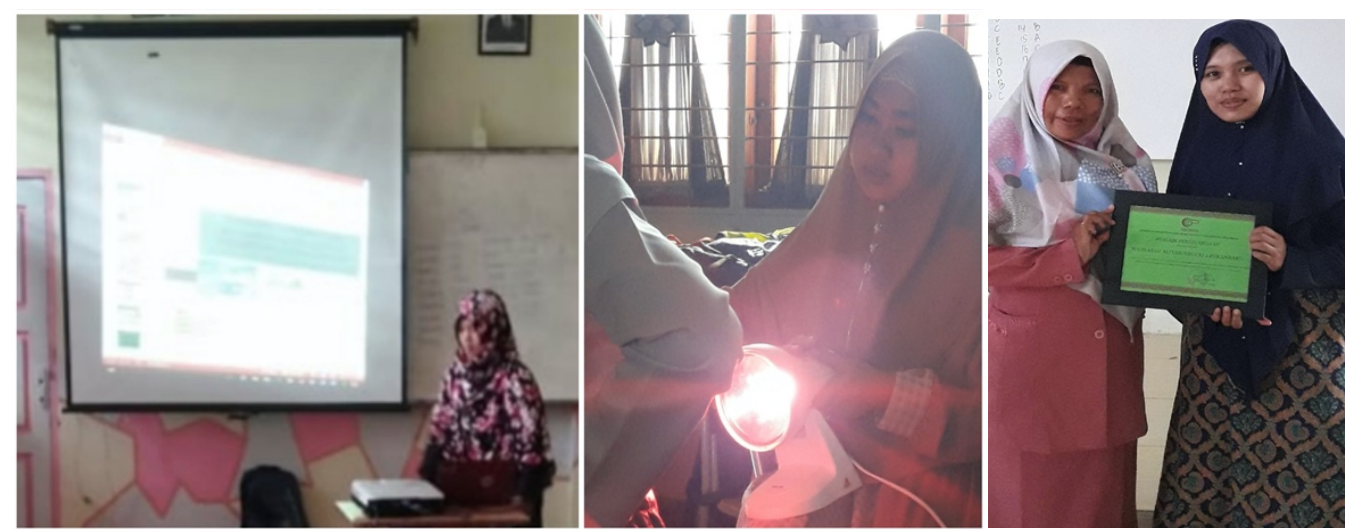

Gambar 1: Dokumentasi Pengabdian

Metode Penerapan kami bagi tiga point, yaitu susunan tim pelaksana, bentuk teknis kegiatan, dan ringkasan materi. Susunan tim pelaksana terdiri atas : Dian Cita Sari/ Ketua, Anggota: Ismaningsih, Renni Hidayati, Wirda Hayati, Mahasiswa : Diki Ananda. 
Bentuk kegiatan pengabdian kepada masyarakat berjudul: Edukasi Kasus Low Back Pain dengan Modalitas Infrared dan Wiliam Flexion Exercises, dilaksanakan dengan rincian sebagai berikut:

Tabel 1. Uraian waktu pelaksanaan kegiatan Program Pelatihan

\begin{tabular}{|c|l|c|}
\hline No. & \multicolumn{1}{|c|}{ Kegiatan } & Waktu \\
\hline 1 & Penyampaian materi bersifat teori LBP, IR, WFE & 1 x pertemuan @,30 M \\
\hline 2 & Penyampaian materi bersifat demontrasi & 1 x pertemuan @,30 M \\
\hline 3 & Praktek Pembelajaran kelas kreatif & 1 x pertemuan @,20 M \\
\hline 4 & Evaluasi dan pengayaan & 1 x pertemuan @,20 M \\
\hline & Jumlah & 1 x pertemuan @ 100 M \\
\hline
\end{tabular}

\section{KESIMPULAN}

Dari pelaksanaan Pengabdian kepada Masyarakat ini, kami capai kesimpulan berupa terwujudnya upaya peran serta Fakultas Kedokteran dan ilmu kesehatan, Universitas Abdurrab untuk meningkatkan pemahaman kasus Low Back Pain Myogenic dalam posisi duduk siswa dengan modalitas IR \& WFE, mengimplementasikan Tri Dharma Perguruan Tinggi, menjalin kerjasama yang saling menguntungkan antara lingkungan akademik dengan pihak sekolah, mengembangkan Kesadaran urgensi Kesehatan Siswa, meningkatkan pengetahuan siswa, serta mendorong partisipasi siswa untuk belajar dengan posisi duduk yang benar.

\section{DAFTAR PUSTAKA}

Juniantari Ayu, Dkk. 2018. Intervensi Micro Mave Diathermy dan Slow Stroke Back Massage Lebih Efektif Dibandingkan Micro Mave Diathermy dan William Flexion Exercise dalam Meningkatkan Kemampuan Fungsional pada Kasus Myogenic Low Back Pain. Denpasar : Fakultas Kedokteran ( simdos.unud.ac.id diunggah 14 januari 2019.

Mardiati Ratna. 2010. Susunan Saraf Otak Manusia. Jakarta : CV Agung Seto.

Mcphee Stephen. 2009. Patologi Penyakit. Jakarta: EGC Kedokteran 